\title{
Impact of Trade Associations on Entrepreneurial Traits in Nigeria's Transport Industry
}

\author{
Ugboaja P.C, Ikeogu C.C, Ogwude I.C and Chikwendu D. \\ Dept. Of Transport Management Technology, Federal University of Technology, PMB 1526 Owerri, Imo State
}

\begin{abstract}
The focus of this study is to determine the extent to which the roles of trade associations foster entrepreneurial traits in Nigeria's road transport industry. This paper offers an analytical assessment of the contribution of trade associations towards development of entrepreneurial traits. To do this, the survey method was adopted for the study and questionnaires were used as data collection method. A random of one hundred and forty four (144) trade associations in Nigeria's road transport industry were selected for the study out of a population of two hundred and twenty four (224) trade associations with seven hundred and twenty (720) respondents. For completeness, a sample of six hundred and fifty seven (657) related organizations (infinite population) were included in the study. Therefore a total of one thousand, three hundred and seventy seven (1377) questionnaires were used for the study. The data collected were measured in 5-point likert scale with a hypothesized mean of 3.00. data analysis revealed that overall mean scores of trade associations' procompetitive and anti-competitive roles on entrepreneurial traits were 1.9346 and 4.4188 respectively. The test of hypothesis using two sample z-test showed that the Z-calculated value for differences in the two mean scores was 216.0147 with significance probability of $<0.0001$ which is less than 0.05 . Thus the test was significant at $5 \%$ level of significance $(P<0.05)$. We therefore reject the null hypothesis and accept the alternative hypothesis. Consequently we conclude that the effect of anticompetitive role is significantly higher than that of procompetitive role of trade associations on the development of entrepreneurial traits in Nigeria's transport industry
\end{abstract}

Key words: Trade associations, Entrepreneurial, Traits, Transport, Industry

\section{Introduction}

There is a distinction between theoretical and operational definitions of entrepreneurship. In general, the theoretical definitions are wide, covering a number of entrepreneurial activities, whereas the operationalized definitions cover a singular aspect Chandler (1990) defines entrepreneurship as dealing with uncertainty, making a distinction between risk, which can be calculated, and uncertainty, which cannot. Schumpeter (1934) describes the entrepreneur as the bearer of the mechanism for change and economic development, and entrepreneurship as the undertaking of new ideas and new combinations, that is innovations. Drucker (1985) describes the entrepreneur as a person who is willing to risk his capital and other resources in new business venture, from which he expects substantial rewards if not immediately, then in the foreseeable future. Okpara (2000) sees the entrepreneur as an individual who has the zeal and ability to find and evaluate opportunities. He further observes that they are calculated risk-takers, who enjoy the excitement of challenges, not necessarily gamblers. The role of entrepreneurship has been different across countries. Holcombe (1998) claims that, "the engine of economic growth is entrepreneurship." Entrepreneurship has been assessed as a driving force of decentralisation, economic restructuring and movement in the direction of market economy (Smallbone, et al., 1996).

Informal sector participation has been described as a trap associated with impoverishment (Cassim 1982) and as the survivalist responses of marginalised persons with no alternatives (Habib 2005). This 'marginalist' perspective prescribes an identity to informal sector participants, with little consideration given to individual potential and individual action as a means to escape impoverishment and a survivalist condition. Of late, however, the structuralist perspective has prevailed, with increasing attention being paid to the informal sector as an entrepreneurial space (see Debrah 2007; Snyder 2004; Williams 2007; Webb, Tihanyi, Ireland \& Sirmon 2009). Here, the informal sector is seen to be a dynamic and vibrant source of entrepreneurial activity, and of a 'hidden' enterprise culture that needs to be harnessed and graduated into the formal sector. And the transport industry is part of this sector.

Continuing global economic and political turmoil worldwide is generating many challenges never before seen or even imagined for governments and businesses. But it is equally generating many new opportunities for road transport operators with the entrepreneurial spirit to grab them and for the trade association, which so proudly represents the road transport industry. The road transport industry is indeed instrumental in interconnecting all businesses to all major world markets, driving trade, creating employment, ensuring a better distribution of wealth and uniting mankind. It plays a crucial role in the daily economic and 
social life of industrialised and developing countries alike. For this reason, researchers have shown considerable interest in transportation studies.

In Nigeria however, previous studies on the subject of road transportation have tended to concentrate on the physical and infrastructural aspects of the transport system. Others include the issue of rail road competition, the geography of road transportation, road transportation as a business enterprise, the rise of entrepreneurs in Nigerian motor transport industry. In spite of this, we can still say that there has been a general neglect of the study of the role and impact of the trade associations on entrepreneurial traits in Nigeria's road transport industry. Today, the road transporters in Nigeria number over one and a half million people (Olubomehin, 2012). Given their sheer number, the group exerts a considerable influence on the country"'s national life. Yet this impact is often over-looked. This paper attempts to fill this gap. It provides an insight to the roles and impact of the trade associations in promoting entrepreneurial traits in the transport industry in Nigeria. The specific objectives of this study is to assess the extent to which trade associations' roles fosters entrepreneurial traits in Nigeria's transport industry. Providing answer to the above objective is an important way in which this paper differ from previous studies on road transportation in Nigeria.

\section{Understanding entrepreneurial traits}

One particular way to reflect on the entrepreneurial potentials of the transport industry is through the notion of 'entrepreneurial traits', which is taken to consist of a number of dimensions, namely, innovativeness, competitive aggressiveness, risk-taking propensity, autonomy and proactiveness. According to Cahill (1996), a state of fragmentation exists in entrepreneurship research. Some theorists believe that the unique values and attitudes of individuals drive entrepreneurial behaviour (Cunningham \& Lischeron 1991), and different perspectives exist in terms of the development of entrepreneurial theory. An entrepreneur has been primarily conceived as a bearer of risk (Carland, Hoy \& Carland 1988), yet primarily as a combiner of resources and an innovator (Schumpeter 2002). However, according to Gartner (1988), the focus of entrepreneurship should be the creation of a venture. The use of the entrepreneurial traits construct provides a conceptual framework that 'pulls together' these different conceptions and allows for the operationalisation of entrepreneurship in entrepreneurship research, in that it considers entrepreneurship as entrepreneurial behaviour.

The five component dimensions of Entrepreneurial traits - namely, innovativeness, autonomy, proactiveness, competitive aggressiveness and risk-taking propensity, as suggested by Lumpkin and Dess (1996) - are briefly discussed below.

\section{Innovativeness}

For Schumpeter (2002), the "purest type of entrepreneur genus" is "the entrepreneur who confines himself most strictly to the characteristic entrepreneurial function, the carrying out of new combinations", in a word: 'innovation'. According to Lumpkin and Dess (1996), innovativeness reflects a tendency for an enterprise "to engage in and support new ideas, novelty, experimentation, and creative processes that may result in new products, services, or technological processes". Innovation is an important means of pursuing opportunities and so is an important component of an entrepreneurial traits.

\section{Autonomy}

Lumpkin and Dess (1996) believe that an "independent spirit" is necessary for entrepreneurship, and autonomy refers to independent action in terms of "bringing forth an idea or a vision and carrying it through to completion", including the concept of free and independent action and decisions taken. "A tendency toward independent and autonomous action" is a key component of an entrepreneurial traits, since intentionality must be exercised.

\section{Proactiveness}

Proactiveness is related to initiative and first-mover advantages, and to "taking initiative by anticipating and pursuing new opportunities". Proactiveness is associated with leadership, and with not following, as a proactive enterprise "has the will and foresight to seize new opportunities, even if it is not always the first to do so", according to Lumpkin and Dess (1996). Proactiveness is considered to differ from competitive aggressiveness, relating to market opportunity in entrepreneurship by "seizing initiative and acting opportunistically in order to shape the environment". The creation of demand, and growth willingness, is therefore considered a measure in this study for proactiveness.

\section{Competitive aggressiveness}

Competitive aggressiveness, "refers to a firm's propensity to directly and intensely challenge its competitors to achieve entry or improve position" and is characterised by responsiveness in terms of confrontation or reactive action. In contrast to proactiveness, which relates to market opportunities, competitive 
aggressiveness refers to how enterprises "relate to competitors" and "respond to trends and demand that already exist in the marketplace".

\section{Risk-taking propensity}

Methods or styles of management associated with risk-taking are an indication of an entrepreneurial traits; however, in terms of different contexts, the effects of the dimensions of entrepreneurial traits, including risk-taking propensity, were expected to differ in terms of their effect on performance according to the specific context, risk-taking propensity is a behavioural dimension of an entrepreneurial trait along which opportunity is pursued.

\subsection{Understanding trade associations What do trade associations do?}

An assessment of the role of trade associations in the labour market, particularly on employment creation requires a more holistic analysis of trade associations. Hence this section tries to answer that by looking at the role of trade associations in development. This has been manifested in having directly contributed to improving standards of living for their members by negotiating not only decent wages, but benefits such as medical, housing, pension and so forth, which all contribute to improving the living standards of working people. The role of trade associations which moves beyond workplace collective bargaining is one that moves away from the simplistic notion of trade associations as organizations who represent the interests of a specific group of people - wage earners and places trade associations at the centre of the overall development agenda of a nation. The Webb's define a trade association as "a continuous association of wage-earners for the purpose of maintaining or improving the conditions of their employment" ( cited by Hyman 2001). This definition narrows the role of trade associations to collective bargaining whilst the literature included in this report shows that the role of trade association goes beyond dealing with workplace issues and only representing wage earners. Trade association's influence in the broader society is manifested in the power that they posses which comes from collectivism. Webster (1974) identifies this power as structural power which workers have in the workplace. Webster (1974) argues that workers in the workplace can "only improve their position if they can combine to put an end to the competition between themselves. Through combination they can turn their numbers, the source of their weakness, into a source of power. This is the essential purpose of a trade association" (Webster 1974). However, it should be noted that different circumstances calls for different types of power which may also dictate the different forms of association adopted by trade associations. The involvement of trade associations in development is illustrated by the role that trade associations in developing countries played during the liberation struggles. Trade associations in developing countries which were previously colonised were key players in the democratisation process of their countries. Furthermore, some trade associations went beyond the fight for the national liberation and became key developmental agents in their societies. The newly elected governments expected the associations to continue with this role and prioritise it after independence (Webster 2007). It is within this context that the role of trade associations by and large has exceeded its initial limited scope based on the Webb's definition. However, an analysis of the role of trade associations in development requires an interrogation of the nature of trade associations and how this influences the role they play in society.

\subsection{The National Union of Road Transport Workers (NURTW)}

The first discernible way in which the motor transporters impacted on the society was that they constituted an important segment within the economy. Such was their growing importance that by 1934 they formed a union, the Nigerian Road Transport Union. The formation of a motor transport union was a new development in colonial Nigeria as such never previously existed. The union was meant to defend and further the collective interests of the motor transporters within the colonial setting. Thus in the 1930s, it fought and successfully resisted attempts by the colonial government to impose higher duties on vehicles in areas where road transport was competing with the railway (Oshin, 1990).

In 1978, a milestone occurred in the history of the road transporters in Nigeria with the formation of the National Union of Road Transport Workers popularly known as the (NURTW). Since this date, the activities of the road transporters have revolved around the NURTW. The NURTW membership, broadly defined, include individuals (mainly male), who are involved in the use of different modes of transport such as motorbikes (motorcycles), buses, cabs, tankers and tricycles - for conveying passengers and goods from one destination within the country to another. The need for orderliness prompted members of the sector to form two associations, namely the Road Transport Employers Association of Nigeria [RTEAN] and the National Union of Road Transport Workers [NURTW]. Though the RTEAN predates NURTW, it is less active than the NURTW, which was registered as a trade union in 1978, and is an affiliate of the Central Labour Organisation [CLO], now known as the Nigerian Labour Congress [NLC]. While the RTEAN is less known, the NURTW has grown overtime, with its membership burgeoning on daily basis. Thus, it boasts of over "1.5 million membership 
throughout the federation" (The NURTW Diary, 2011). With the exclusion of petroleum tanker drivers, all professional commercial drivers are automatic members of the Union. As such, the NURTW serves as an umbrella body for drivers operating motorbikes, taxi cabs, tricycles, buses (both intra and inter-state services), trailers and lorries that engage in the conveyance of passengers and goods.

The main objectives of the Union is to promote the economic welfare of its members. The extent to which these unions has impacted entrepreneurial traits on its members is an issue for an empirical discourse.

\section{Research methods}

A quantitative study was undertaken of one hundred and forty four (144) trade associations in Nigeria's road transport industry were selected for the study out of a population of two hundred and twenty four (224) trade associations with seven hundred and twenty (720) respondents. For completeness, a sample of six hundred and fifty seven (657) related organizations (infinite population) were included in the study. Therefore a total of one thousand, three hundred and seventy seven (1377) questionnaires were used for the study. The data collected were measured in 5-point likert scale with a hypothesized mean of 3.00. The hypothesis was tested using the Z-test statistic.

\section{Research Question}

\section{Results and discussion}

To what extent does the role of trade associations foster the development of entrepreneurial traits in Nigeria's transport Industry?

Table 1: Impact of the roles of trade associations on the development of entrepreneurial traits in Nigeria's transport industry.

Table 1a. Pro-competitive roles

\begin{tabular}{|c|c|c|c|c|}
\hline \multirow{3}{*}{$\begin{array}{l}\text { ITEM } \\
\text { item-22 }\end{array}$} & DESCRIPTION & MEAN & STO OEV & OBS \\
\hline & Conducts that positively influence & 2.5984 & 1.2537 & 1377 \\
\hline & government policies & & & \\
\hline \multirow{3}{*}{ item-16 } & Commercial services, namely, legal & & & \\
\hline & assistance to members, insurance & 2.0450 & 0.2968 & 1377 \\
\hline & and risk solutions, finance solutions & & & \\
\hline \multirow{3}{*}{ item-17 } & and vehicle inspection services & & & \\
\hline & Conferences, Workshops and & 2.0450 & 0.3337 & 1377 \\
\hline & Seminars & & & \\
\hline item-21 & Technical and Compliance support & 2.0334 & 0.3520 & 1377 \\
\hline item-20 & Media Relations & 2.0102 & 0.2800 & 1377 \\
\hline item-19 & Crisis Control & 1.6964 & 0.5263 & 1377 \\
\hline item-18 & Collection of Cost Index data & 1.1140 & 0.4861 & 1377 \\
\hline overall & & 1.9346 & 0.2894 & 1377 \\
\hline
\end{tabular}

Table 1b Anti-competitive roles

\begin{tabular}{|c|c|c|c|c|}
\hline ITEM & DESCRIPTION & MEAN & SrD DEV & !OBS \\
\hline item-30 & Management guidance and decisions & 4.9194 & 0.3121 & 1377 \\
\hline & that lead to restraints on competition & & & \\
\hline \multirow{4}{*}{ item-27 } & Conducts that restrict the entry of & \multirow{4}{*}{4.9187} & & \multirow{3}{*}{1377} \\
\hline & firms into legitimate services and & & 0.4096 & \\
\hline & operations & & & \\
\hline & Hoarding of information provided by & & & \multirow{3}{*}{$\begin{array}{c}1377 \\
1377\end{array}$} \\
\hline \multirow{2}{*}{$\begin{array}{l}\text { item-29 } \\
\text { item-23 }\end{array}$} & Government Regulatory Agencies & 4.8954 & 0.4830 & \\
\hline & Conducts that restrict prices & 4.8264 & 0.6677 & \\
\hline \multirow[t]{2}{*}{ item-28 } & Unfair trade practices & 3.9884 & 0.1864 & 1377 \\
\hline & & 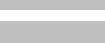 & & 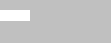 \\
\hline \multirow{3}{*}{$\begin{array}{l}\text { item-24 } \\
\text { item-25 }\end{array}$} & Conducts that restrict quantities & 3.9535 & 0.3014 & 1377 \\
\hline & Conducts that restrict customers and & 3.9303 & 0.3338 & 1377 \\
\hline & sales channels & & & \multirow{3}{*}{1377} \\
\hline \multirow[t]{2}{*}{ item-26 } & Conducts that restrict facilities and & 3.9187 & 0.3802 & \\
\hline & technology & & & \\
\hline \multicolumn{2}{|l|}{ overall } & 4.4188, & 0.3137 & 1377 \\
\hline
\end{tabular}


Tables $1 \mathrm{a}$ and $1 \mathrm{~b}$ above show the extent to which pro-competitive and anti- competitive roles of trade associations respectively affect the development of entrepreneurial traits in Nigeria's transport industry. Table 1a shows that the extent to which each of the seven (7) pro-competitive roles considered in the study, affects the development of entrepreneurial traits in Nigeria's transport industry is below average. This is because they all have mean scores less than the expected value 'of 3.00 on a 5-point Likert scale. However, the pro- competitive role that has the highest effect on the development of entrepreneurial traits in Nigeria's transport industry is item -22 (Conducts that positively influence government policies) with a mean score of 2.5984 . This is followed by item-16 (Commercial services, namely, legal assistance to members, insurance and risk solutions, finance solutions and vehicle inspection services) and item-17 (Conferences, Workshops and Seminars) with a mean score of 2.0450. The pro-competitive role that has the least effect on the development of entrepreneurial traits in Nigeria's transport industry is item-18 (Collection of Cost Index data) with a mean score of 1.1140. The overall effect of all the seven (7) pro-competitive roles on the development of entrepreneurial traits in Nigeria's transport industry is 1.9346 , which is less than the expected value of 3.00 on a 5-point Likert scale. This means that the extent to which pro-competitive roles of trade associations affect the development of entrepreneurial traits in Nigeria's transport industry is generally below average.

Similarly, table $1 \mathrm{~b}$ shows that the extent to which each of the eight (8) anti- competitive roles considered in the study, affects the development of entrepreneurial traits in Nigeria's transport industry is above average. This is because they all have mean scores greater than the expected value of 3.00 on a 5 -point Likert scale. The anti-competitive role that has the highest effect on the developmet of entrepreneurial traits in Nigeria's transport industry is item-30 (Management guidance and decisions that lead to restraints on competition) with a mean score of 4.9194 . This is followed by item-27 (Conducts that restrict the entry of firms into legitimate services and operations) with a mean score of 4.9187. The anti-competitive role that has the least effect on the development of entrepreneurial traits in Nigeria's transport industry is item-26 (Conducts that restrict facilities and technology) with a mean score of 3.9187. The overall effect of all the eight (8) anticompetitive roles on the development of entrepreneurial traits in Nigeria's transport industry is 4.4188 , which is greater than the expected value of 3.00 on a 5-point Likert scale. This means that the extent to which anticompetitive roles of trade associations affect the development of entrepreneurial traits in Nigeria's transport industry is generally above average. Consequently, we conclude that the effects of pro-competitive roles of trade associations on the development of entrepreneurial traits in Nigeria's transport industry are severally and jointly below average, while the effects of the anti-competitive roles are severally and jointly above average Test of Hypothesis

Ho: The effect of anti-competitive roles is not significantly higher than that of pro-competitive roles of trade associations on the development of entrepreneurial traits in Nigeria's transport industry.

Hi: The effect of anti-competitive roles is significantly higher than that of pro-competitive roles of trade associations on the development of entrepreneurial traits in Nigeria's transport industry

Table 2: Two sample $\mathrm{z}$ test for differences in the effects of pro-competitive and anti-competitive roles of trade associations on' the development of entrepreneurial traits in Nigeria's transport industry

\begin{tabular}{lll}
\hline \multicolumn{1}{c}{ Variable } & traits-n & traits-p \\
Mean & 4.4188 & 1.9346 \\
Known Variance & 0.0984 & 0.0837 \\
Observations & 1377 & 1377 \\
Hypothesized Mean Difference & 0 & \\
z-calculated & 216.0147 & \\
$\mathrm{P}(\mathrm{Z}<=\mathrm{z})$ one-tail & $<0.0001$ \\
$\mathrm{z}$-tabulated (one-tail) & 1.6449 & \\
$\mathrm{P}(\mathrm{Z}<=\mathrm{z})$ two-tail & $<0.0001$ \\
$\mathrm{z}$-tabulated (two-tail) & 1.9600 & \\
\hline
\end{tabular}

Table 2 shows the two sample $\mathrm{z}$ test for differences in the effects of pro- competitive and anti-competitive roles of trade associations on the development of entrepreneurial traits in Nigeria's transport industry. The table shows that the mean scores for the effects of pro-competitive and anti- competitive roles of trade associations on the development of entrepreneurial traits in Nigeria's transport industry are 1.9346 and 4.4188 respectively. This means that the effect of anti-competitive roles of trade associations or the I development of entrepreneurial traits in Nigeria's transport industry is higher than that of the procompetitive roles. The z-calculated value for differences in the two mean scores is 216.0147 with a Significance (one-tail) probability of $<0.0001$, which is less than 0.05 . Thus the test is significant at $5 \%$ level of significance $(P<0.05)$. We therefore reject the null hypothesis and accept the alternative 
hypothesis.

\section{Conclusion and recommendation}

Consequently, we conclude that the effect of anti- competitive roles is significantly higher than that of pro-competitive roles of trade associations on the development of entrepreneurial traits In Nigeria's transport industry. This means that trade associations major roles do not foster development of entrepreneurial traits in Nigeria's transport industry. In light of the foregoing, we recommend that efforts should be made by governments to simultaneously promote trade associations pro-competitive roles and inhibit the growth of anti-competitive roles. Invariably Government should introduce measures to discourage anti-competitive roles especially in areas of; management guidance and decisions that lead to restraints on competition, conducts that restrict the entry of firms into legitimate services and operations and hoarding of information provided by Government regulatory Agencies, i.e. (items 30, 27 and 29) in table 1b. In the same vein they should provide incentive measures to promote pro-competitive roles such as collection of cost index data, crisis control and media relations ie items 18,19 and 20 respectively in table 1a.

\section{References}

[1] Cahill, D. 1996. 'Entrepreneurial orientation or pioneer advantage', Academy of Management Review, 21 (3): 603-605.

[2] Chandler, A. (1990). Entrepreneurship and Economic Growth. Cambridge, Harvard University Press.

[3] Carland, J.W., Hoy, F. \& Carland, J.A.C. 1988. "“Who is an entrepreneur?” is a question worth asking', American Journal of Small Business, 12(4): 33-39.

[4] Cassim, F. 1982. 'Labour market segmentation: The theoretical case', South African Journal of Economics, 50(4): 240-247

[5] Cunningham, J.B. \& Lischeron, J. 1991. 'Defining entrepreneurship', Journal of Small Business Management, 29(1): 45-61.

[6] Debrah, Y. 2007. 'Promoting the informal sector as a source of gainful employment in developing countries: Insights from Ghana', International Journal of Human Resource Management, 18(6): 1063-1084.

[7] Drucker, P. F. (1985). Innovation and Entrepreneurship. Practice and Principles. London, Heinemman.

[8] Holcombe, R. (1998). Entrepreneurship and Economic Growth. The Quarterly Journal of Austrian Economics 1.

[9] Habib, A. 2005. 'State-civil society relations in post apartheid South Africa', Social Research,72(3): 671-690.

[10] Hyman. R. 2001. Understanding European Trade Unionism: Between Market, Class and Society. London: Sage Lumpkin, G.T. \& Dess, G.G. 1996. 'Clarifying the entrepreneurial orientation construct

[11] and linking it to performance', Academy of Management Review, 21(1): 135-173.

[12] NURTW Diary, 2011. Road Transport and the Declining Fortunes of the Nigeria Railway, 1901 - 1950. The Journal of Transport History, Third Series, 12, 2, 11-36.

[13] Okpara, F.O. (2000). Entrepreneurship: Test and Cases, Enugu, Precision Printers and Publishers.

[14] Oshin, O. 1990. Rail and Road Transport Competition in Nigeria, 1904 - 1950. In F. Toyin (ed.), Modern Nigeria: A Tribute to G.O. Olusanya. (62-89). Lagos, Modelor.

[15] Schumpeter, J. 2002. 'Entrepreneurial profit', In Krueger, N.F. (ed), Entrepreneurship: Critical Perspectives on Business and Management. London: Routledge.

[16] Snyder, K. 2004. 'Routes to the informal economy in New York's east village: Crisis, economics, and identity', Sociological Perspectives, 47(2): 215-240.

[17] Webb, J., Tihanyi, L., Ireland, R. \& Sirmon, D. 2009. 'You say illegal, I say legitimate: Entrepreneurship in the informal economy', Academy of Management Review, 34(3): 492-510.

[18] Webster, E.1974. The case of African Unions. South African Labour Bulletin. Vol 1, No. 1: South Africa Webster. E. 2007. Trade Unions and Political Parties in Africa: New Alliances. Strategies and partnerships. FES Briefing papers No.3/ 2007

[19] Williams, C. 2007. 'The nature of entrepreneurship in the informal sector: Evidence from England', Journal of Developmental Entrepreneurship, 12(2): 339-254. 